Instructions for authors, subscriptions and further details:

http://ijep.hipatiapress.com

\title{
In-service Teachers' Sense of Agency after Participation in a Research Master Course
}

Maria Antonietta Impedovo ${ }^{1}$

1) Aix Marseille Univ, ADEF, Marseille, France

Date of publication: October $24^{\text {th }}, 2016$

Edition period: October 2016 - February 2017

To cite this article: Impedovo, M. A. (2016). In-service Teachers' Sense of Agency after Participation in a Research Master Course. International Journal of Educational Psychology, 5(3), 281-307. doi: 10.17583/ijep.2016.2206

To link this article: http://dx.doi.org/10.17583/ijep.2016.2206

\section{PLEASE SCROLL DOWN FOR ARTICLE}

The terms and conditions of use are related to the Open Journal System and to Creative Commons Attribution License (CC-BY). 


\section{In-Service Teachers' Sense of Agency after Participation in a Research Master Course}

Maria Antonietta Impedovo

Aix Marseille Université

\section{Abstract}

In this paper, we investigate the in-service teachers 'sense of agency' after their participation in a research master course. A semi-structured interview was administrated to nine in-service science teachers, coming from three different African countries: Zimbabwe, Lesotho, and Burkina Faso. All of them attended a European master course aimed to acquire skills in science educational research. The data collected was qualitatively analysed through a system of categories. This paper aims to contribute to the discussion about the professionalisation of teacher education and the integration of research into teacher training.

Keywords: In-service teacher, research skills; science educational, teacher agency. 


\section{Sentido de Agencia del Profesorado en Servicio después de Participar en un Curso de un Máster de Investigación}

Maria Impedovo

Aix-Marseille Université

\section{Resumen}

En este trabajo, se investiga el 'sentido de agencia' de los maestros en servicio después de su participación en un curso de máster de investigación. Una entrevista semiestructurada se administró a nueve profesores de ciencias en servicio, procedentes de tres países diferentes de África: Zimbabue, Lesoto, y Burkina Faso. Todos ellos asistieron a un curso de máster europeo destinado a adquirir habilidades de investigación en educación. Los datos recogidos se analizaron cualitativamente mediante un sistema de categorías. Este artículo tiene por objeto contribuir a la discusión acerca de la profesionalización de la formación del profesorado y la integración de la investigación en la formación docente.

Palabras clave: Maestro en servicio, habilidades de investigación, ciencias de la educación, agencia del maestr 


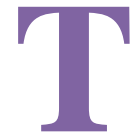

oday, the figure of the teacher must respond to new needs and demands due to an evolving educational system, as recognised in the national and international policy and research literature (Bates, Swennen \& Jones, 2011; European Commission, 2013). In particular, in-service teachers -being full-time employees- need to continuously update their role and keep up with the constant evolution of society (Iannaccone, Tateo, Mollo \& Marsico, 2008). Teachers are required to be able and willing to address the educational changes and to innovate their teaching practices (Kompf, Bond, Dworet \& Boak, 1996). Reforms are important in science education, where there is a general dissatisfaction with how science is traditionally taught (Bybee \& DeBoer, 1994), with the need to support also the professional development of science teachers (Munby, Cunningham, \& Lock, 2000).

For this reason, more and more in-service teachers project themselves towards professional and academic training. Growing attention for teachers is about acquiring research skills. Indeed, teacher educators are expected to be excellent in both teaching and in researching (Berry, 2007). We consider that the acquisition of research skills in science education for in-service teachers can bring a development and an enrichment of their professional identity. Indeed, learning always provides an ontological change in identity (Lahn, 2011; Packer, 1999), achieved through active participation in a community (Brown \& Campione, 1990; Wenger 1998). So, through the learning process, teachers can incorporate new ways of being (Vågan, 2011), with personal and social transformation (Packer \& Goicoechea, 2000). In particular, we are interested in how the development of research skills and attitude influence the sense of agency, considered as capacity to initiate purposeful action that implies will, autonomy, freedom and choice (e.g. Bandura, 2006; Biesta \& Tedder, 2006; Ecclestone, 2007; Edwards \& D'Arcy, 2004; Gillespie, 2012; Holland, Lachicotte, Skinner \& Cain, 1998). We suggest that teachers' agencies support the implementation of innovation in teaching practices.

In order to pursue this aim, we have administrated a semi-structured interview to nine in-service science teachers. They belong to three different African countries (Zimbabwe, Lesotho, and Burkina Faso) and all have attended an international full-time master programme aimed to acquire skills of science educational research. Through several interviews, we will explore 


\section{Impedovo - Teachers' Sense of Agency}

the in-service science teachers' sense of agency one year after attending an educational research course.

In the first part of the paper, we consider the influence of research skills on supporting professional development, with reference to teachers' identity and sense of agency. Finally, we present the data results with a qualitative analysis. This paper aims to contribute to the discussion about the professionalisation of teacher education and the integration of research in teacher training.

\section{Learning Research Skills}

There is a growth of research on practice conducted by teacher education practitioners themselves (Cochran-Smith, 2005; Lampert, 2000; Loughran, Hamilton, LaBoskey, \& Russell, 2004). This trend started from teachers that consider academic research not relevant to their needs or is written in a way that fails to help them understand their classroom situation. So, the research question may stem from researchers' or teachers' own questions about everyday classroom practice, or in common agreement (Postholm, 2008; Postholm \& Madsen, 2006). Cochran-Smith (2005) suggests that part of the task of the teacher educator is to function simultaneously as both researcher and practitioner, stressing the blurring boundaries between the two roles (Cochran-Smith \& Lytle, 1999). This perspective takes into account the dual demands of being both a teacher, the practice, and a researcher, contributing to the public knowledge base of teachers' education (Dobber et al, 2005).

Teacher research is mainly linked to the action research (Cochran-Smith \& Lytle 1999; Meier \& Henderson, 2007), understood as research designed by practitioners to seek practical solutions to issues and problems in their professional and social lives (Stringer, 2007; Anderson \& Herr, 1999). Indeed, through the research, teachers gain insights into teaching and learning, becoming a reflective activity, affecting changes in the local scholastic community, and improving students' learning (Cochran- Smith \& Lytle, 1999). So, teachers' research conducted individually or collaboratively helps firtsly to understanding teaching and learning in context (Meier \& Henderson, 2007). Although these questions and reflections are context-specific, the teachers' research enables teachers to 
link theory and practice (Bullough \& Gitlin, 2001). It generates new "local" knowledge about teaching and learning (Stremmel, 2007).

Training on research skills for in-service teachers became an opportunity to acquire new meaning, new processes for decision making (Van Huizen, Van Oers, \& Wubbels, 2005), new knowledge and skills to be implemented in their practices. Teachers involved in the research can development a "researcherly disposition", defined as the habit of mind to engage in research (Cochran-Smith, 2003; Munn, 2008). Tack \& Vanderlinde (2014) theoretically extended this construct as "teacher educators' researcherly disposition", referring to cognitive component (the knowledge about educational research, research methods and practitioner research), a behavioural aspect (to be engaged in research, integrating the results into individual teaching practice) and an effective aspect to the teaching profession. Also, during the process of involving, the teachers may also learn some strategies to use in future development activities (Postholm, 2008).

To be involved in the research community gives teachers the possibility to acquire new rules, practices and processes that affect their identity (Brown \& Campione, 1996; Wenger, 1998). Indeed, according to Girod and Pardales (2001) "the process of becoming a teacher-researcher is powerful because it challenges teachers core beliefs and values about themselves and the work they do, it forces them to confront who they are as teachers and who they want to be as professionals" (p.3). For these reasons, we consider that attending a master course aimed at develop research skills would sustain teachers' identity and nourish a teacher's agency, important dimensions to supporting innovation, as we will explain in the next section.

\section{Teachers' Identity: Sense of Agency}

Teacher agency refers to the specific teachers' agency in performing activities in schools. It is seen as an important dimension of teacher professionalism (Priestley, Biesta \& Robinson, 2012) and it is a significant concept for teacher professional identity development (Beijaard, Meijer \& Verloop, 2004; Vloet \& Van Swet, 2010). Indeed teachers' agency in relation to professional identity allows examine how teachers experience the world of school (Achinstein, Ogawa, \& Speiglman, 2004), in relation to 
educational practices (Schweisfurth, 2006). Emirbayer and Mische (1998) suggest that agency should be understood as a temporally embedded process of social engagement, influenced by the past (in its habitual aspect), oriented towards the future (as a capacity to imagine alternative possibilities) and engaged with the present (in the contingencies of the moment). This threedimensional perspective on agency generates a new understanding of how agency is achieved in concrete situations, and of the different factors which might promote or inhibit the achievement of agency. In their ecological view, Priestley, Biesta and Robinson (2012) see the agency as an emergent phenomenon that results from the interplay of individual efforts, available resources and contextual and structural factors. Agency is, therefore, related to what people do and achieve in a specific context (Biesta \& Tedder, 2006). Bullough and Gitlin's (2001) study looks at the tension between what the context demands of the individuals and what they are or really want to be. Sannino (2009) discusses the concept of experience to highlight a positive connection between resistance and agency, and its potential for teachers' professional development and educational change. Chia, Zhang and Ye (2010), in a case study, show how existing and emerging structure/resources enabled and developed teacher agency in sustaining and scaling up a pedagogical innovation. These views make agency "a contextually enacted way of being in the world" (van Lier, 2008).

In this paper, we intend to explore how participation in a master course, expressly devoted to improving research skills, may impact teachers'sense of agency after one year. This analysis will be performed though the use of the interview, considered in a socio-cultural perspective, as "dialogical social events based on repertoires of socially and culturally embedded and constantly changing words and discourses" (Tanggaard, 2015).

\section{Method}

\section{Research Question}

Our research is guided by the following question: How do in-service teachers draw on different modalities to characterize their own agency when 
reflecting on their participation in a master course on research skills attended one year before?

\section{Participants}

This work is a follow-up study of a previous research initiative to study teachers' agency (Impedovo \& Ligorio, 2016). We interviewed nine inservice teachers (six men and three females), who constituted a whole class of a full-time international master course. The course is a master on Educational Research sponsored by the European Program Erasmus Mundus. The main aim of this two years full-time master was to improve teaching skills in science educational research by also sustaining a research attitude. The main subjects were: methodology of research, statistics, innovative educational approaches in sciences education, and use of educational technology in the classroom. They all came from three African countries (Zimbabwe, Lesotho and Burkina Faso) with structural problems in the education system, such as the lack of basic resources and teachers low qualifications (Haßler, Hennessy, Cross, Chileshe \& Machiko, 2015). At the same time, these countries recognise the importance of the technology and science as an engine for innovation (OECD, 2008, 2014).

Their average age is around 39 years (the youngest is 30 and the most senior is 50 years old). All have a bachelor in educational science gained in their respective countries. Their teaching subjects are mainly biology, mathematics and/or physics. They have different seniority in teaching service at high school as full-time teachers: two of them have less than five years; four of them between 10 to 15 years and the remaining three more than 20 years of teaching experiences. They all teach in a higher school, and three of them are teacher educators in high school and university. All speak English as a second language (at different levels of fluency).

Teachers were contacted one year after the end of the international master and they accepted to be interviewed. At the time of the interview, all the participants were living in their respective countries and had obtained the official qualification after the discussion of their final research dissertation in science education, based on data collected in their local school. A common dissertation' topic was the use of simulation software and ITC for teaching science education. Details of the interview are in Appendix. 


\section{Impedovo - Teachers' Sense of Agency}

\section{Data collection}

The collect narrative data about research skills and attitude comprise a semistructured interview (Patton, 2002). The interview contained eight questions around two topics:

- Participation in the master course: dissertations; difficulties; implication on personal and community level;

- Involving in the research: interest and involving in new research; the implication of research on teaching practices.

The interview was conducted with Skype and, when it was not possible, we used a synchrony chat. The interviewer used the mirroring technique (Rogers, 1967). We used the narrative interview in our study since we believe that this qualitative method allows us to reflect on selected experiences and events in order to make them meaningful (Watson, 2006), bringing out their sense of agency. Through considering the language in the narrative in teachers' stories it was possible to examine their agency (e.g. Shaw, 2001).

\section{Data-analysis}

A qualitative method has been used to analyse the data collected. The texts of the interviews were read and analyzed by two independent researchers. The reading phase is crucial to familiarize with the content of the interviews and to break down the parts of the text expressing similar ideas. Then, our thematic analysis of the content was performed, consisting of an iterative and circular process between theoretical concepts, research questions, and empirical data (Bryant \& Charmaz, 2007; Charmaz, 2006). During this process, some discrepancies were found and resolved through discussions and clarification until an agreement was reached. Below, we proceed to describe in detail the six modalities of agency considered through the analysis and the linguistic analysis performed on the corpus data.

\section{Six modalities of agency}

From the methodological point of view, agency is a broad concept, and we are aware that it is difficult to capture considering the large number of claims made about agency within different traditions. For this study, taking 
into consideration Jyrkämä (2008) and the following work of Sairanen \& Kumpulainen (2014), we consider six modalities for the analysis of sense of agency. These six modalities of agency, reported as follows, were used as analytic tools:

- To want, positions the person in question as wanting to do something;

- $\quad$ To know, ascribes the person with certain knowledge and know-how;

- To be able, characterizes the physical abilities and limitations of the person;

- Have to, ascribes a must or something that the person has to do;

- To feel, experience, appreciate, positions the person as being able to feel and experience, and lastly;

- To have the possibility ascribes the person as having possibilities to do something in a given situation.

These modalities are understood, following the discussion of Sairanen \& Kumpulainen (2014), as a socially constructed relation between an individual's perspective (made of aspirations, opportunities and limitations) and a given practice. Adopting this perspective, we compiled a joint guideline for identifying these six modalities of agency from the data, and with it, we analysed the interviews.

\section{Guideline and the linguistic analysis}

We attend to various linguistic features for the analysis of agency. In particular by looking at the use of pronouns ( $I$, we, my, our), use of active verbs (first person or first plural person), statements connected to speakers' desires and intentions ( $I$ will, I choose), and temporal positioning relative to action (Before $I$ do, now $I$ do). These linguistic elements are what are generally used for the linguistic analysis of agency (e.g., Archer, 2000; Duranti, 2004; Kumpulainen, 2014). In Table 1 the Guideline is used to perform the analysis with the six modalities of agency and the main linguistic indicators considered: 
290 Impedovo - Teachers' Sense of Agency

Table 1

Guideline: Modalities, Definition and Indicators

\begin{tabular}{|c|c|c|}
\hline Modalities & Definition & Main linguistic indicators \\
\hline To want & $\begin{array}{l}\text { Positions the person in question } \\
\text { as wanting to do something }\end{array}$ & $\begin{array}{l}\text { Action verbs with expression of } \\
\text { desire or interests (I wish; I am } \\
\text { thinking of looking; I intend...) }\end{array}$ \\
\hline To know & $\begin{array}{l}\text { Ascribes the person with certain } \\
\text { knowledge and know-how }\end{array}$ & $\begin{array}{l}\text { Action verbs with expression of } \\
\text { learning reached (I gained } \\
\text { instructional; I learned that...) }\end{array}$ \\
\hline To be able & $\begin{array}{l}\text { Characterises the physical } \\
\text { abilities and limitations of the } \\
\text { person }\end{array}$ & $\begin{array}{l}\text { Action verbs with expression of } \\
\text { ability obtained (I apply; I use; I } \\
\text { am able), combined with } \\
\text { temporal indicator (now, before } \\
\text {...) }\end{array}$ \\
\hline Have to & $\begin{array}{l}\text { Ascribes a must or something } \\
\text { that the person has to do }\end{array}$ & $\begin{array}{l}\text { Action verbs with references to } \\
\text { duties (I have shared the results; } \\
\text { I did an exhibition ...) }\end{array}$ \\
\hline To feel & $\begin{array}{l}\text { Experience, appreciate, } \\
\text { positions the person as being } \\
\text { able to feel and experience, and } \\
\text { lastly }\end{array}$ & $\begin{array}{l}\text { Action verbs with references to } \\
\text { feeling (It was confusing; I am } \\
\text { so happy...) }\end{array}$ \\
\hline $\begin{array}{l}\text { To have the } \\
\text { possibility }\end{array}$ & $\begin{array}{l}\text { Ascribes the person as having } \\
\text { possibilities to do something in } \\
\text { a given situation }\end{array}$ & $\begin{array}{l}\text { Action verbs with references to } \\
\text { opportunities (I was involved; I } \\
\text { am to join ...). }\end{array}$ \\
\hline
\end{tabular}

\section{Results}

We discuss the results of our study in two phases. First, we highlight how in-service teachers draw on different modalities to characterise their own agency. Second, we focus on what insights can be drawn from in-service teachers' sense of agency regarding the attended course and interests in the research discussed in the interviews. 


\section{In-service Teachers Modalities of Agency}

Below we present the results about the sense of agency in the nine teachers interviewed. In Table 2 we present the emergent themes from the nine inservice teachers' interviews, and we do so according to the six modalities used to explore the sense of agency.

Table 2

Modalities of agency in teachers' reflections

\begin{tabular}{|c|c|c|c|c|c|}
\hline To want & To know & To be able & Have to & To feel & $\begin{array}{l}\text { To have the } \\
\text { possibility }\end{array}$ \\
\hline $\begin{array}{l}\text { To continue } \\
\text { with } \\
\text { research in } \\
\text { local } \\
\text { country }\end{array}$ & $\begin{array}{l}\text { Technology } \\
\text { skills } \\
\text { and } \\
\text { computer } \\
\text { simulations }\end{array}$ & $\begin{array}{l}\text { To apply } \\
\text { instructional } \\
\text { technology } \\
\text { in } \\
\text { classrooms }\end{array}$ & $\begin{array}{l}\text { Manage } \\
\text { the } \\
\text { internation } \\
\text { al master } \\
\text { course }\end{array}$ & $\begin{array}{l}\text { Confused } \\
\text { about final } \\
\text { dissertation } \\
\text { writing } \\
\text { Difficulties }\end{array}$ & $\begin{array}{l}\mathrm{Be} \\
\text { involved in } \\
\text { ministerial } \\
\text { and } \\
\text { national } \\
\text { activities }\end{array}$ \\
\hline $\begin{array}{l}\text { To attend a } \\
\text { specialist } \\
\text { course }\end{array}$ & $\begin{array}{l}\text { Knowledge } \\
\text { in } \\
\text { educational } \\
\text { topics }\end{array}$ & $\begin{array}{l}\text { To reveal } \\
\text { students } \\
\text { 'preconcepti } \\
\text { ons }\end{array}$ & $\begin{array}{l}\text { Shared the } \\
\text { results } \\
\text { with } \\
\text { students }\end{array}$ & $\begin{array}{l}\text { in collecting } \\
\text { data } \\
\text { Happy to }\end{array}$ & $\begin{array}{l}\text { To } \\
\text { encourage } \\
\text { local }\end{array}$ \\
\hline $\begin{array}{l}\text { Looking for } \\
\text { new job to } \\
\text { have more }\end{array}$ & $\begin{array}{l}\text { Be aware of } \\
\text { students' }\end{array}$ & $\begin{array}{l}\text { To improve } \\
\text { teaching }\end{array}$ & $\begin{array}{l}\text { and } \\
\text { colleagues }\end{array}$ & $\begin{array}{l}\text { have learned } \\
\text { research } \\
\text { skills }\end{array}$ & $\begin{array}{l}\text { schools to } \\
\text { adopt ICT } \\
\text { in }\end{array}$ \\
\hline $\begin{array}{l}\text { time to do } \\
\text { research }\end{array}$ & $\begin{array}{l}\text { misconcepti } \\
\text { ons }\end{array}$ & approach & $\begin{array}{l}\text { To work } \\
\text { on research }\end{array}$ & Need for & classroom \\
\hline $\begin{array}{l}\text { To do a } \\
\text { doctorate }\end{array}$ & $\begin{array}{l}\text { Familiar and } \\
\text { competent to } \\
\text { do research }\end{array}$ & $\begin{array}{l}\text { Incorporate } \\
\text { research } \\
\text { knowledge } \\
\text { in teaching }\end{array}$ & papers & $\begin{array}{l}\text { more } \\
\text { reading and } \\
\text { access to } \\
\text { research }\end{array}$ & \\
\hline $\begin{array}{l}\text { To write } \\
\text { academic } \\
\text { papers }\end{array}$ & $\begin{array}{l}\text { A broader } \\
\text { base of } \\
\text { teacher } \\
\text { resources }\end{array}$ & & & database & \\
\hline
\end{tabular}


In what follows, we analyse each modality in detail through the use of inservice teachers interviews' extracts.

\section{To Want}

Teachers express in different ways their sense of agency related to "to want". They express essentially their desire to continue to do research in their local community, in the hope of making a contribution to their country: "I am now satisfied with my research thesis and wishes to research some other issues affecting the educational system in Vanuatu" (Male, 31 years, Vanuatu).

Also there is the aspiration to look for new job to have more time to do research, having therefore the opportunity to publish some papers about their topics:

I am still working as a High School teacher and I am very much interested in continuing with research. I want to further my studies so that I can frequently manage to undertake research activities. Since there is a lot of work at high school, I am thinking of looking for a job that can comfortably allow me to continue with research. (Female, 44 years, Lesotho)

To archive this, they express the willingness to enrol in a specialist course and also in a doctorate level course:

I am still very much interested in it. That is the reason I want to go further and do a doctorate on the same subject. (...). I have not published any article or report as yet but $\mathbf{I}$ intend to do so very soon. (Male, 51 years, Lesotho)

\section{To Know}

Thanks to the participation in the international master course aimed to develop research skills and attitude, during interviews all teachers claim to have developed ITC knowledge and skills, especially related to technological education and computer simulations: "I have gained instructional technology skills to improve students learning. I also gained knowledge about current affairs and areas of concerns in science education and education research methods" (Female, 44 years, Lesotho). 
At the same time, the master course allowed them to broaden their knowledge of theoretical issues, by making them aware of students' misconceptions, a central topic in their master course in science education: "I learned that computer simulations can be used as an alternative method of teaching. I learned that students come to the classroom with different ideas on a topic, some which may be correct others which may be wrong" (Male, 38 years, Zimbabwean).

This theoretical knowledge, gained through lessons and didactical materials, has allowed them to broader teacher resources, changing also teaching perspectives:

My research made me look beyond boundaries of a classroom. It made me look at students as people who are potentially capable of achieving knowledge only if you put the writing tools in their hands and point them in the right direction. (Male, 31 years, Vanuatu)

\section{To be Able}

The teachers declared to be able and feel more confident to apply instructional technology in classrooms, a new area for almost all of them, with direct impact on student learning:

The research improved my teaching practices a lot. I now apply instructional technology in my classrooms. I now use computer simulations and Youtube videos in my lessons and encourage learners to research from the internet, all of which were not done before. I am now able to provoke them to reveal the preconceptions they have before instruction. (Female, 44 years, Lesotho)

Teachers also feel confident to explore deeper subjects of science education thanks to the acquired ability to access to academic resources: "I now have a broader base of teacher resource support material from the internet" (Male, 35 years, Zimbabwe).

In general, teachers have the common perception to be able to do research in science education: "My main personal advantage is that $\mathbf{I}$ am now familiar with research and am competent to do any research in the arena of education and others as well" (Male, 31 years, Vanuatu). 


\section{Have to}

This modality ascribes a must or something that the person has to do. In relation to this, the teachers express they have had to manage the international course during the master course. This activity was not always simple, considering the involvement of three countries and three respective universities in the Erasmus project. The second important element is that teachers express is the "mission" to share the results of their research dissertations with their students, colleagues, schools and community:

I have shared the results with students who were participants, the teachers who were also taking part in the study and through a conference organised by the National University of Lesotho, I shared the results with teachers from Tertiary institutions and high schools who in preparation for publishing in their journal at national and regional level. (Female, 44 years, Lesotho)

The sharing of results has been proposed in various ways, through the activities of presentations: "I did an exhibition representing the local university, I also encourage my colleges at the school to use the simulations during staff development meetings" (Male, 35, Zimbabwe) or indirect through the sharing of artefact produced "I shared with my colleagues by letting them read my paper" (Male, 51 years, Lesotho).

\section{To Feel}

Teachers express that they felt confused about how to reach a final decision about their dissertation: "Having a common understanding on issues from supervisors from the three universities. Sometimes it was confusing to reach the final decision about the way forward. Adaptation to two countries of different cultures and approaches to people was also a challenge" (Female, 44 years, Lesotho). And, during the research, they express difficulties in the involvement of participants in collecting data. A more general feeling is in the difficulties for the use of technological resource in school, like computers but mainly the Internet:

Time was not enough for undertaking the research especially when I had to be teaching the students and at the same time conduct a research. Access to Internet facilities was a big challenge. Most of the time the 
signal was very poor. I could not use the school computers instead I had to use my own laptop, connect it to an overhead projector, then allow one student to be operating the laptop while the rest had to answer and fill the worksheets. (Female, 50, Lesotho)

The difficulty of access to the Internet is considered a limitation in access to useful resources and existing, that can add value to the lesson: "I could not access some of the important journals which I intended to use for my research even from the university website" (Male, 35, Zimbabwe). Nevertheless, teachers express happiness to have learned research skills, regarded as "tools" to be used for putting into practice innovation activities access: "I am so happy to have learned the skills to do research. It is the only way to find a possible solution to issues faced inside a society" (Male, 31 years, Vanuatu).

\section{To have the Possibility}

This last sense of agency modality ascribes the person as having possibilities to do something in a given situation. In our case, after the participation in the master course, the teachers have had the opportunity to be involved in a nationally relevant official activity: "I was also involved in writing a professional report at International level for Ministry" (Female, 44 years, Lesotho) or for disseminations:

To reach the science teachers and students is to be involved in projects and participating in TV presentations on "how can biology be best taught in the classroom". There is a program like this in our Lesotho Television.

I am preparing at the moment some 20 -minute presentations on some biology topics that will take off from January 2016. As a researcher to improve my skills I am to join the National University Team of Researchers next year 2016. (Female, 50 years, Lesotho)

Finally, teachers think their participation in the master course has supported their classroom or sometimes the entire school to adopt ICT in teaching and learning activities: "The main contribution of my research was to encourage schools in my community to adopt the use of ICT into the teaching methodology and how to use it effectively" (Male, 31 years, Vanuatu). Indeed, their reach to change the attitude of some colleagues or sometimes of all the school about the limitation in the use of ICT, with 


\section{Impedovo - Teachers' Sense of Agency}

relevant changes: "The school has adopted the use of computers in lessons and is no longer limiting teachers' access to the internet during working hours" (Male, 35 years, Zimbabwe).

\section{Discussion}

In this paper, by drawing on the sociocultural framework and narrative semiotics, we have addressed in-service teachers 'sense of agency' as they reflect on their participation in a master course. Teachers express their sense of agency in different ways related to the different modality of agency.

About the 'want', they express essentially their desire to continue to do research in their local community, in the hope of giving a contribution to their country. Indeed Stremmel and Horm-Wingerd (2007) encompass a view of teaching as an inquiry process, useful in seeking practical solutions to real problems in their professional and social lives. They express the need of a research inside a real-life context of the classroom and the voice of the teacher (Davis, 2007).

This desire is so high to orient some of them to a change in the profession, with a higher investment in education (like the choice to do a doctorate course). So personal learning includes a reflective orientation to oneself and to the local conditions of the learning community (Calderhead, 1996). In this sense, in-service teachers' sense of agency is strictly linked to the context and local community (Gallagher, 2012).

About the 'to know' all teachers claim to have developed ITC knowledge and skills, especially related to technological education and computer simulations. Theoretical knowledge -gained through lessons and didactical materials- has allowed them to utilise broader teacher resources, changing also teaching perspectives. Indeed, teachers who have been involved in research may become more reflective, more critical and analytical in their teaching, and more open and committed to professional development (Oja \& Pine 1989; Henson, 1996).

At the same time, they feel more confident applying instructional technology in classrooms, with direct impact on student learning. Also, teachers have the common positive perception to be able to do research in science education. The master course has given them the basic tools to know about research in science education. The discussion is open on how to 
evaluate the quality of teacher research, in order to ensure the quality and authenticity of teacher research (Cochran-Smith \& Donnell, 2006). However, there is agreement that standards for rigour must be maintained (Anderson \& Herr, 1999; Freeman, deMarrais, Preissle, Roulston, \& St. Pierre, 2007; Zeichner \& Noffke, 2001).

They feel the "mission" to share the results of their research dissertations with their students, colleagues, schools and community. The development of a knowledge base for teaching practice is considered as a shared responsibility among teachers themselves, looking to the involvement of schools and institutions (Bickel \& Hattrup, 1995). This attitude helps to develop the community and can make possible subsequent learning communities (Hargreaves, 2003; Oosterheert \& Vermunt, 2001). For teachers, sharing is important to implement "inquiry communities", understood as a setting where learning is visible and accessible to others (Cochran-Smith, 2005).

Teachers express some difficulties in doing the research in the local context, especially considering the ITC and internet restriction, with consequent limitation in the access to the resources. Nevertheless, teachers express happiness to have learned research skills, regarded as "tools" to be used for putting into practice innovation activities access. This positive perception helped to establish a harmonious relationship between personal identity, aspirations and enthusiasm for the profession (Korthagen, 2004; Korthagen \&Verkuyl, 2007).

Teacher research has helped to introduce a significant change in local teachers 'context, in helping schools develop a new curriculum methods with the use of ITC and starting to build new institutional network, with universities or others schools. The participation in the course and the research conducted on local context has given them the opportunity to become an active voice, contributing to the discourse constructed by and maintained by that community. Becoming a subject in a community also means becoming an active agent, and this is based on the subject's reflective awareness. In the same time also the community co-develops with its members on the basis of the exteriorization of members 'activity in practise of collective interest (Van Oers, 2002).

In general, thanks to the research training, teachers have in general understood that they can improve teaching and create the possibility of 


\section{Impedovo - Teachers' Sense of Agency}

transformation and renewal of their community. So, as stressed by Stremmel (2007) it is important to reconceptualise the role of teacher and teachers research, in an intertwinement of personal, social, and educational change (Meier \& Henderson 2007; Stremmel, 2007).

\section{Conclusion}

The utilisation of the sense of agency modality contributes to describing inservice teacher narratives that constituted the actors of the story (Fontanille, 2006; Greimas \& Porter, 1977). The applicability of the modalities of agency as analytical tools helped to understand how in-service teachers perceive themselves as authors of their professional growth. Although our conceptualizations are based on in-service teachers' narrated interview accounts of their sense of agency rather than an examination of agency in action, our study paves the way for future research in this regard.

Finally, teacher research is a path for lifelong learning in the profession, supporting reflective and mindful teaching, and self-transformation to develop a better understanding of teachers themselves, their classrooms, and their practice (Mills 2000; Stringer 2007; Stremmel, Fu, \& Hill 2002). In an age of accountability, more than ever, teachers, schools, and school districts need to be actors in introducing and supporting innovation.

\section{Acknowledgement}

I sincerely thank the participants who dedicated their precious time to interviews. I also want to acknowledge the passion they showed for their professional development.

\section{References}

Achinstein, B., Ogawa, R. T., \& Speiglman, A. (2004). Are we creating separate and unequal tracks of teachers? The effects of state policy, local conditions, and teacher characteristics on new teacher socialization. American educational research journal, 41(3), 557603. doi: 10.3102/00028312041003557

Anderson, G., \& Herr, K. (1999). The new paradigm wars: Is there room for rigorous practitioner knowledge in schools and universities? 
Educational researcher, 28(5), 12-21. doi:

10.3102/0013189X028005012

Archer, M. (2000). Being human: The problem of agency. Cambridge:

Cambridge University Press.

Bandura, A. (2006). Toward a psychology of human agency perspectives.

Psychological science, 1, 164-180. doi: 10.1111/j.1745-

6916.2006.00011.x

Bates, T., Swennen, A., \& Jones, K. (2011). The professional development of teacher educators. London, England: Routledge.

Beijaard, D., Meijer, P. C., \& Verloop, N. (2004). Reconsidering research on teachers' professional identity. Teaching and teacher education, 20, 107-128. doi: 10.1016/j.tate.2003.07.001

Berry, B. (2007). The national board for professional teaching standards and the future of a profession. Prepared for the National Board for Professional Teaching Standards 2020: Clarifying a vision for quality teaching. Racine, WI.

Bickel, W.E., \& Hattrup, R.A. (1995). Teachers and researchers in collaboration: Reflections on the process. American educational research journal, 32(1), 35-62. doi: 10.3102/00028312032001035

Biesta, G.J.J. \& Tedder, M. (2006). How is agency possible? Towards an ecological understanding of agency-as-achievement. Working paper 5, Exeter, The learning lives project.

Bybee, R.W., \& DeBoer, G.E. (1994). Research on goals for the science curriculum. In D.L. Gabel (Ed.), Handbook of research on science teaching and learning (pp. 357 - 387). New York: Macmillan.

Brown, A., \& Campione, J. (1996). Psychological theory and the design of innovative learning environments: On procedures, principles, and systems. In L. Schauble \& R. Glaser (Eds.), Innovations in learning: New environments for education (pp. 289-325).

Mahwah, NJ: Lawrence Erlbaum Associates.

Bullough, R.V., \& Gitlin, A. D. (2001). Becoming a student of teaching: Linking knowledge production and practice. 2nd ed. New York: Routledge Falmer.

Bryant, A., Charmaz, K. (2007). Grounded Theory Research: Methods and Practices. In Bryant, A. and Charmaz, K. (Eds.) The Sage Handbook of Grounded Theory, Sage, Los Angeles. 
Calderhead, J. (1996). Teachers' knowledge and beliefs. In D. C. Berliner, \& R. C. Calfee (Eds.), Handbook of educational psychology. New: Macmillan and APA.

Charmaz, K. (2006). Constructing Grounded Theory: A Practical Guide Through Qualitative Analysis. London: Sage.

Chia, C., Zhang, B., Ye, X. (2010). Fostering teacher agency for scaling up an iMVT innovative pedagogy for science learning. Paper presented at the 14th Global Chinese Conference on Computers in Education, Singapore, p. 679- 682.

Cochran-Smith, M. (2003). Learning and unlearning: the education of teacher educators. Teaching and teacher education, 5-28. ISSN: ISSN-0742-051X

Cochran-Smith, M. (2005). Teacher educators as researchers: Multiple perspectives. Teaching teachers, 21(2), 219-225. doi:

10.1016/j.tate.2004.12.003

Cochran-Smith, M., \& Donnell, K. (2006). Practitioner inquiry: Blurring the boundaries of research and practice. In J. Green, G. Camilli, \& P.B. Elmore (Eds.) Handbook of complementary methods in education research (p. 503-518). Mahwah, NJ: Lawrence Erlbaum.

Cochran-Smith, M., \& Lytle, S.L. (1999). The teacher research movement: A decade later. Educational Researcher, 28(7), 15-25. doi: 10.3102/0013189X028007015

Cooper, K., \& Olson, M. R. (1996). The multiple of teacher identity. In M. Kompf, W. R. Bond, D. Dworet, \& R. T. Boak (Eds.), Changing research and practice: teachers professionalism, identities and knowledge (pp. 78-89). London: Falmer Press.

Davis, S. H. (2007). Bridging the gap between research and practice: What's good, what's bad, and how can one be sure? Phi delta kappan, 88(8), 568-78. doi: 10.1177/003172170708800804

Dobber, M., Akkerman, S. F., Verloop, N., \& Vermunt, J. D. (2012).

Student teachers' collaborative research: Small-scale research projects during teacher education. Teaching and teacher education, 28(4), 609-617. doi:10.1016/j.tate.2012.01.009 
Duranti, A. (2004). Agency in Language. In A. Duranti (Ed.), A Companion to Linguistic Anthropology (pp. 451-473). Malden, MA: Blackwell.

Ecclestone, K. (2007). An identity crisis? The importance of understanding agency and identity in adults' learning, Editorial. Studies in the Education of Adults, 39(2), 21-28.

Edwards, A. \& D'arcy, C. (2004). Relational agency and disposition in sociocultural accounts of learning to teach. Educational review, 56(2), 147-155. doi: 10.1080/0031910410001693236

Emirbayer, M., \& Mische, A. (1998). What is agency? American journal of sociology, 103(4), 962-1023. doi: 10.1086/231294

European Commission. (2013). Supporting teacher educators for better learning outcomes. Strasbourg: European Commission.

Fontanille, J. (2006). Semiotics of discourse. New York: Peter Lang.

Freeman, M., deMarrais, K., Preissle, J., Roulston, K. \& St. Pierre, E. (2007). Standards of evidence in qualitative research: An incitement to discourse. Educational researcher, 36(1), 25-32. doi: 10.3102/0013189X06298009

Gallagher, S. (2012). Multiple aspects in the sense of agency. New ideas in psychology 30(1), 15-31. doi:10.1016.2010.03.003

Gillespie, A. (2012). Position exchange: The social development of agency. New ideas in psychology, 30(1), 32-46. doi:

10.1016/j.newideapsych.2010.03.004

Girod, M. \& Pardales, M. (2001). “Who am I becoming?” Identity development in becoming a teacher researcher. Paper presented at the annual meeting American Educational Research Association, Seattle, WA.

Greimas, A. \& Porter, C. (1977). Elements of a narrative grammar.

Diacritics, 7(1), 23-40. doi: 10.2307/464872

Haßler, B., Hennessy, S., Cross, A., Chileshe, E. \& Machiko B. (2015).

School-based professional development in a developing context:

lessons learnt from a case study in Zambia. Professional development in education, 41(5), 806-825. doi:

$10.1080 / 19415257.2014 .938355$

Hargreaves, A. (2003). Teaching in the knowledge society; Education in the age of insecurity. New York: Teachers College Press. 
Henson, K.T. (1996). Teachers as researchers. In J. Sikula, T. Buttery, \& E. Guyton (Eds.), Handbook of research on teacher education (5364). New York: Simon \& Schuster.

Holland, D., Lachicotte, W., Skinner, D., \& Cain, C. (1998). Identity and agency in cultural worlds. Cambridge: Harvard University Press.

Iannaccone, A., Tateo, L., Mollo, M., \& Marsico, G. (2008). L'identité professionnelle des enseignants face au changement: analyses empiriques dans le contexte italien. Travail et formation en éducation, 2. Retrieved from http://tfe.revues.org/754

Impedovo, M. A., Ligorio, M. B. (2016). Participating in an international masters' programme: impact on agency for African in-service teachers. Professional Development in Education, 1-3. doi: 10.1080/19415257.2016.1146624.

Jyrkämä, J. (2008). Agency, aging and everyday life: a sketch of a theoretical-methodological framework. Gerontologia, 22(4), 190203.

Kompf, M., Bond, W. R., Dworet, D., \& Boak, T. (1996). Changing research and practice: Teachers professionalism, identities and knowledge. London: Falmer Press.

Korthagen, F. A. J. (2004). In search of the essence of a good teacher: towards a more holistic approach in teacher education. Teaching and teacher education, 20, 77-97. doi: 10.1016/j.tate.2003.10.002 Korthagen, F., \& Verkuyl, H. S. (2007). Do you encounter your students or yourself? The search for inspiration as an essential component of teacher education. In T. Russel \& J. Loughran (Eds.), Enacting a Pedagogy of Teacher Education. Values, relationships and practices (pp.106-123). London: Routledge.

Kumpulainen, K. (2014). Researching engagement, agency and coconstruction of meaning in educational interactions. EARLI Jure 2014 Conference Nicosia, Cyprus June 30, 2014.

Kvale, S. (2007). Doing interviews. Thousand Oaks, CA: Sage. Lahn, L. C. (2011). Professional learning as epistemic trajectories. In S. Ludvigsen, A. Lund, I. Rasmussen \& R. Säljö (Eds.) Learning across sites. New tools, infrastructures and practices (pp. 53-69). New York: Routledge. 
Lampert, M. (2000). Knowing teaching: the intersection of research on teaching and qualitative research. Harvard educational review, 70(1), 86-99.

Loughran, J., Hamilton, M. L., LaBoskey, V., \& Russell, T. (Eds.). (2004). International handbook of research of self. Study of teaching and teacher education practices. Amsterdam: Kluver.

Meier, D.R., \& Henderson, B. (2007). Learning from young children in the classroom: The art and science of teacher research. New York: Teachers College Press.

Mills, G. (2000). Action research: A guide for the teacher researcher. Upper Saddle River, NJ: Merrill/Prentice-Hall.

Munby, H., Cunningham, M., \& Lock, C. (2000). School science culture: A case study of barriers to developing professional knowledge.

Science education, 84, 193 - 211. doi:10.1002/(SICI)1098237X(200003)84:2<193::AID-SCE4>3.0.CO;2-K

Munn, P. (2008). Building research capacity collaboratively: can we take ownership of our future? British educational research journal, 34, 413-430. doi: 10.1080/01411920802065664

OECD (2008). Reviews of national policies for education - South Africa. OECD Publishing.

OECD (2014). Reviews of vocational education and training a skills beyond school. Review of South Africa. OECD Publishing.

Oja, S.N., \& Pine, G.J. (1989). Collaborative action research: teachers' stages of development and school contexts. Peabody journal of education, 64(2), 96-115. doi: 10.1080/01619568709538553

Oosterheert, I. E., \& Vermunt, J. D. (2001). Individual differences in learning to teach: relating cognition, regulation and affect. Learning and instruction, 11(2), 133-156. doi: 10.1016/S09594752(00)00019-0

Packer, M. (1999). The Ontology of learning. Paper presented at AERA, Montreal, Canada.

Packer, M. J. \& Goicoechea, J. (2000). Sociocultural and constructivist theories of learning: Ontology, not just epistemology. Educational Psychologist, 35(4), 227-241. doi: 10.1207/S15326985EP3504_02

Patton, M. Q. (2002). Qualitative research and evaluation methods. Thousand Oaks, CA: Sage. 


\section{Impedovo - Teachers' Sense of Agency}

Postholm, M. B. (2008). Teachers developing practice: reflection as key activity. Teaching and teacher education, 24(7), 1717-1728. doi: 10.1016/j.tate.2008.02.024

Postholm, M.B., \& Madsen, J. (2006). The researcher's role: an ethical dimension. Outlines, 7(1), 49-60.

Priestley, M., Biesta, G.J.J. \& Robinson, S. (2012). Understanding teacher agency: The importance of relationships. A paper presented at the Annual Meeting of the American Educational Research Association, Vancouver, Canada, 13-17 April 2012. Retrived from: http://www.stir.ac.uk/media/schools/education/documents/teachera gency/Teacher\%20agency_AERA\%20paper_final.pdf

Rogers, C. R. (1967). Client-centered therapy. Baltimore, MD: Williams and Wilkins.

Roulstona, K., Legettea, R, Deloacha, M. \& Pitmana, B. (2005). What is 'research' for teacher-researchers? PitmanEducational Action Research,13(2), 169-190. doi: 10.1080/09650790500200283

Sairanen, H. \& Kumpulainen, K. (2014). A visual narrative inquiry into children's sense of agency in preschool and first grade.

International journal of educational psychology, 3(2), 141-174. doi: 10.4471/ijep.2014.09

Sannino, A. (2009). Teachers' talk of experiencing: conflict, resistance and agency. Teaching and teacher education, 26, 838-844. 5. doi: 10.1016/j.tate.2009.10.021

Schweisfurth, M. (2006). Education for global citizenship: teacher agency and curricular structure in Ontario schools. Educational review, 58(1), 41-50. doi: 10.1080/00131910500352648

Shaw, D. G. (2001). Happy in our chains? Agency and language in the postmodern age. History and theory, 40(4), 1-9. http://www.jstor.org/stable/2677984

Stremmel, A. J. (2007). The value of teacher research: nurturing professional and personal growth through inquiry. Voices of practitioners 2(3).

Stremmel, A.J., Horm-Wingerd, D. (2007). Voices of practitioners-Teacher research: nurturing professional and personal growth through inquiry. National association for the education of young children.

Stremmel, A.J, V.R. Fu, \& L.T. Hill. (2002). The transformation of self in early childhood teacher education: Connections to the Reggio 
Emilia approach. In V.R. Fu, A.J. Stremmel, \& L.T. Hill (Eds.) Teaching and learning: Collaborative exploration of the Reggio Emilia approach, p. 135-45. Upper Saddle River, NJ:

Merrill/Prentice Hall.

Stringer, E.T. (2007). Action research. Thousand Oaks, CA: Sage. van Huizen, P., van Oers, B., \& Wubbels, T. (2005). A Vygotskian perspective on teacher education. Journal of curriculum studies, 37( 3), 267 290. doi: 10.1080/0022027042000328468

van Oers, J.A.M. (ed.) 2002. Health on course? The 2002 Dutch Public Health Status and Forecasts Report. Houten: Bohn Stafleu Van Loghum.

Tack, H., \& Vanderlinde, R. (2014). Teacher educators' researcherly disposition: cleaning up a messy construct. NAFOL National conference, Abstracts. Presented at the 2014 NAFOL National conference: Once a teacher, always a teacher, NAFOL.

Tanggaard, L. (2015). The research interview as a dialogical context for the production of social life and personal narratives. Qualitative inquiry, 15(9), 1498-1515. doi: 10.1177/1077800409343063

Vågan, A. (2011). Towards a sociocultural perspective on identity formation in education. Mind, Culture, and Activity, 18(1), 43-57. doi: $10.1080 / 10749031003605839$

Van Lier, L.(2008). Agency in the classroom. In J. P. Lantolf \& M. E. Poehner (Eds.). Sociocultural theory and the teaching of second languages (p.163-86). London: Equinox.

Vloet, K. \& Van Swet. J. (2010). I can only learn in dialogue! Exploring professional identities in teacher education. Professional development in education, 36(1), 149-168. doi:

$10.1080 / 19415250903457083$

Watson, C. (2006). Narratives of practice and the construction of identity in teaching. Teachers and Teaching. Theory and Practice, 12(5), 509526.

Wenger, E. (1998). Communities of practice. Leaning, meaning, and identity. Cambridge: Cambridge University Press.

Zeichner, K.M., \& Noffke. S.E. (2001). Practitioner research. In V. Richardson (Ed.), Handbook of research on teaching (pp. 298- 
306 Impedovo - Teachers' Sense of Agency

330). Washington, DC: American Educational Research Association.

Dr. Maria Antonietta Impedovo is researcher and teaching assistant in Aix-Marseille Université in France (ADEF).

Contact Address: ENS Lyon, ADEF EA4671, 13248, Aix-Marseille Université, Marseille, France. Dr. Impedovo's e-mail address: mariaantonietta.IMPEDOVO@univ-amu.fr 


\section{Appendix}

\section{Interview Protocol}

1. Which have been the main advantage and difficulties in doing your research during the international master course?

2. After one year from the international master course, are you still interested in your research topic?

3. At the retour in your country, did you share the results of your research with colleagues/students or other schools? In which way?

4. In your opinion, what is the most important contribution of your research in your school or/and community?

5. Do you think that have done your research have had an impact in your teaching practices? In which way?

6. Have you published or do you plan to write articles about your research?

7. Are you involved in new research project?

8. Do you intend to improve your professional skills? In which way? 